\title{
On the Possibility of Marxist Ethics
}

\section{Marxist Etiğin Olană̆g Üzerine}

\author{
BUKET KORKUT RAPTIS B \\ Muğla Sitkı Koçman University
}

Received: II.02.2018 | Accepted: I6.06.20I8

\begin{abstract}
Marx avoided elaborating an ethical theory and criticized utopian socialism. Although Marx's attitude towards these two issues is discussed separately in the literature, we will argue that they stem from the same ground in Marx. It is Marx's devotion to scientific socialism that grounds his criticisms. We will first discuss the opposition between utopian and scientific socialism as Marx understood it. After elaborating some Marxist approaches in this debate, we will argue that any attempt at reconciling Marxism with ethics must be utopian in nature. Finally, we will give some Nietzschean arguments for explaining why a conception of utopia is indispensable for developing a Marxist theory of ethics.
\end{abstract}

Keywords: Marx, Nietzsche, ethics, morality, utopia, revolution.

(C) Korkut Raptis, B. (2018). On the Possibility of Marxist Ethics. Beytulhikme An International fournal of Philosophy, 8 (I), I3I-I55. 
The communists do not preach morality at all.

They [Utopian Socialists] want to improve the condition of every member of society, even that of the most favoured. Hence, they habitually appeal to society at large, without the distinction of class; nay, by preference, to the ruling class. For how can people, when once they understand their system, fail to see in it the best possible plan of the best possible state of society?

(Marx \& Engels)

\section{Introduction}

Marx did not develop a view of ethics. This, however, does not mean that Marxist ethics is impossible. This paper will question its possibility. Hence, our regulative question in this paper is: How is Marxist ethics possible? An answer to this question will give us the claims one has to presuppose for developing a version of Marxist ethics. In short, it will determine, what we may call, 'the presuppositions of Marxist ethics.' This is the task of this paper, to provide us with at least some of these presuppositions. ${ }^{\text {I }}$

We should first distinguish between what Marx said and how we might eventually re-organize what he said. The latter I call a Marxist thesis. A Marxist thesis aims to re-organize Marx's ideas in such a way that a better vision of truth is seen. Hence it is an improved version of Marx's view. There should be such a difference between Marx's view and a Marxist thesis. The former is the concern of history of philosophy. The latter, namely, developing a Marxist thesis, however, is an original work of philosophy. ${ }^{2}$ This paper aims at a Marxist thesis rather than a presen-

\footnotetext{
A presupposition is a necessary claim (one should endorse) for the possibility of (proposing) a supposition. Here, our supposition is that Marxist ethics is possible. And we just want to find out the presuppositions that are necessary for the possibility of developing a Marxist theory of ethics.

2 This is what we shall call abistorical approach to history of philosophy. Historical texts of philosophy are both historical, that is, they represent the view of a concrete indiviual philosopher in history, and ahistorical, that is they attempt to present truth, in other words, they attempt to re-organize the relation among universal truths. Historical texts of philosophy are valuable as resources of universal truths organized in multifarious ways. Hence, philosophical value of these historical texts are, as a rule, ahistorical. What is philosophical is what is ahistorical.

We shall all aim to be both historians of philosophy and original thinkers. But it is quite important to know how to use the history of philosophy for developing an original thesis. What is our ultimate scale? It is truth. We use the resources in history of philosophy in
} 
tation of Marx's view. But in order to develop such a thesis one should first have an understanding of Marx's view. Hence, the paper will also try to present Marx's view in order to develop a Marxist thesis concerning the possibility of Marxist ethics.

The question we shall begin with is this: Can there be a view of ethics compatible with what Marx said about morality? If we distinguish between morality and ethics, it seems to be possible. Morality, one might claim, is a set of cultural norms about what is good and bad. Ethics, however, consists of a theoretical endeavor that questions the sources of good and bad, and attempts to develop a perspective that can lead us to a better life. Although Marx does not propose such a distinction, his target is morality rather than ethics. Marx took morality to be not only irrelevant to revolutionary practice but detrimental to its success. Morality, according to Marx, was ideological in the sense that it was constructed to protect the interests of the ruling class. This means that Marx was a relativist about morality and was not interested in developing an ethical perspective that can break through this relativity. There is nothing contradictory in claiming that morality is relative, but ethics is not. The fact that moral norms change from culture to culture does not mean that there cannot be ethics. Realism about ethics is still possible. ${ }^{3}$ Hence, our answer to our initial question is that there can be a Marxist theory of ethics compatible with what Marx said about morality.

It is beyond the task of this paper to develop a Marxist theory of ethics. Our concern here is not to evaluate contemporary attempts either. We are rather interested in developing some tools for evaluating these kinds of approaches in general. In this direction, we aim to lay out the presuppositions of developing a Marxist theory of ethics. Accordingly, our original question "How is Marxist ethics possible?" can be elaborated as: "What kind of outlook should an ethical perspective have in order to

order to achieve a better vision of truth. We shall try to correct the mistakes of our intellectual ancestors and to improve their view. The original thinkers, namely, philosophers, are our common intellectual ancestors of humanity. They achieved the level of universality, which is the target of all students of philosophy. This is our duty as students: We shall have something more to say to our students than what we learned from our teachers.

One exemplar approach is Aristotle's. It is not a coincidence that there have already been some attempts to develop a Marxist ethics based on Aristotle. See for instance, Alasdair MacIntyre's view, and Paul Blackledge's Marxism and Ethics: Freedom, Desire and Revolution 
be Marxist?" From the perspective of Marx's view, this last question can be expressed as follows: "Is anti-utopian scientific Marxist ethics possible?" We will argue that it is not. Marxist ethics, if it is to be meaningful, should be relevant to revolutionary practice. And for it to be relevant, it should be utopian rather than scientific. But it is well known that Marx was against utopian socialism and Engels sharpened the contrast between utopian and scientific socialism. We shall first examine Marx's and Engels' criticism of utopian socialists, which will be the subject of section one. Then we will turn back to our main question, namely, "How is Marxist ethics possible?" In response, we will argue that the more scientific a Marxist thesis claims to be, the less space is left for the ethical in revolutionary practice. This means that any Marxist attempt to develop a view of ethics is destined to be utopian rather than scientific. This entails that Marxist ethics is possible only through endorsing a version of utopian Marxism, which will be the conclusion of second section. In the final section, we will further discuss how a Nietzschean perspective might help us to develop such a utopian Marxist theory of ethics. A utopian Marxist theory of ethics presupposes that ethical revolution, a revolution that leads to a better life, requires a vision of utopia. Accordingly, we can call an ethical revolution that is based on a vision of utopia a 'utopian revolution.' Therefore, the regulative question of our last section is "How is utopian revolution possible?" Utopian revolution is the conscious attempt of human beings to change the political realm according to a vision of utopia. Hence, the possibility of a utopian revolution is the primary question for any thesis of Marxist ethics. Now, the possibility of utopian revolution presupposes the existence of agents who are able to carry out that revolution. Hence, the question concerning how utopian revolution is possible presupposes that we have an answer to the Nietzschean question: "Who is able to carry out a utopian revolution?" After answering this question from a Nietzschean perspective, we will leave the task of fully elaborating such a Marxist theory of ethics to future studies, for it is beyond the limits of this paper.

\section{Marx's and Engels' Criticism of Utopian Socialism}

For understanding Marx's and Engels' criticism of utopian socialism, we should first look at the views of the utopian socialists, namely, Saint 
Simon, Robert Owen and Charles Fourier. More precisely, we need to uncover what these so-called utopian socialists aimed at. These can be summarized under three headings. They aimed at (I) constructing human/social sciences on the model of the natural sciences; (2) an ethical approach for explaining how to pass from the current state of society to socialism; (3) establishing small-scale communities so as to prove the validity of their claims in (I) and (2).

In this sense, Engels' sharp opposition between utopian and scientific socialism might be misleading for two reasons. First, utopian socialists also aimed at scientific explanation of human social life. ${ }^{4}$ Second, Marx and Engels share the utopian socialists' goal of socialism, understood as a better social world. ${ }^{5}$ This is most explicitly stated in the first draft of The Civil War in France, in a passage dropped from the second draft:

The Utopian founders of sects ... [described] ... the goal of the social movement, the supersession of the wages system with all its economic conditions of class rule ... From the moment the working men's class movement became real the fantastic utopias evanesced - not because the working class had given up the end aimed at by these Utopians, but because they had found

4 For instance, Saint Simon claims: "One concludes necessaily that physiology of which the science of man is part, will be treated by the method adopted for the other physical sciences" (quoted from Durkheim's Socialism and Saint Simon, 63). Owen claims: "The present essays therefore are not brought forward as mere matter of speculation, to amuse the idle visionary..." "I have thus given a detailed account of this experiment... without this, particular facts may indeed amuse or astonish, but they would not contain substantial value which the principles will be found to possess" (A New View of Society and Other Writings, 63; 79). Also, Fourier claims:" I continue my discussion of the filiation of the new sciences. I soon recognized that the laws of passionate attraction were in complete accord with the laws of material attraction as explained by Newton and Leibniz, and there was a unified system of movement governing the material world and the spiritual world... Thus a new exact science was discovered. I advanced into a new scientitic world." (The Utopian Vision of Charles Fourier: Selected Texts on Work, Love and Passionate Attraction, IOIIO2). Furthermore, Vincent Geoghegan, also approves our interpretation when he argues that "The utopian socialists saw themselves as social scientists. 'Utopian' was, for them, a pejorative term, like 'dreamer' or 'visionary', used to describe fanciful schemes divorced realiy. Time and again in their work they asserted their hard-headed, scientific, realistic and practical approach to society. There was nothing 'utopian', as they understood the term, in their methodology." (Utopianism and Marxism, 23).

5 For similar approaches, see David W. Lovell's "Marx's Utopian Legacy"; Roger Paden's "Marx's Critique of the Utopian Socialists"; Krishan Kumar's "Utopian Thought and Communal Practice"; Ruth Levitas' "Beyond Bourgeois Right: Freedom, Equality and Utopia in Marx and Morris" and Vincent Geoghegan's Utopianism and Marxisim. 
the real means to realise them - but in their place came a real insight into the historical conditions of the movement and a more and more gathering force of the militant organization of the working class. But the last two ends of the movement proclaimed by the Utopians are the last ends proclaimed by the Paris Revolution and by the International. Only the means are different and the real conditions of the movement are no longer clouded in utopian fables. (Marx and Engels I980, I66)

Marx and Engels criticize utopian socialists based on three concerns that correspond to the above- mentioned three aims of the utopian socialists. Regarding the first aim of developing a social science, Marx and Engels claim that the social conditions at the time of the utopian socialists were not mature enough for them to understand the dynamics of social change and develop the proper scientific approach that is dialectical materialism. In The Manifesto of the Communist Party, they express this in the following manner:

The socialist and communist systems, properly so called, those of SaintSimon, Fourier, Owen, and others, spring into existence in the early undeveloped period, described above, of the struggle between proletariat and bourgeoisie (see Section I: Bourgeois and Proletarians).

The founders of these systems see, indeed, the class antagonisms, as well as the action of the decomposing elements in the prevailing form of society. But the proletariat, as yet in its infancy, offers to them the spectacle of a class without any historical initiative or any independent political movement. Since the development of class antagonism keeps even pace with the development of industry, the economic situation, as they find it, does not as yet offer to them the material conditions for the emancipation of the proletariat. They therefore search after a new social science, after new social laws, that are to create these conditions. (Marx and Engels 2008, 78)

Even Marx and Engels do not claim here that utopian socialists did not target developing a social science. They rather argue that the scientific approach of utopian socialists was misdirected, due to the lack of empirical evidence. The resources of revolution, according to Marx and Engels, are already embodied in the material conditions of the class conflict between bourgeoisie and proletariat. Since utopian socialists could not foresee the upcoming material conditions they searched after "new 
social laws that are to create these conditions." In other words, they thought that socialism needs to be established. In The German Ideology Marx and Engels oppose to this perspective:

Communism is for us not a state of affairs which is to be established, an ideal to which reality [will] have to adjust itself. We call communism the real movement which abolishes the present state of things. The conditions of this movement result from the now existing premise. (Marx and Engels I998, 57)

This brings us to utopian socialists' second aim and Marx's and Engel's criticism of it. Utopian socialists thought that ethics is the key to social change towards socialism. They were, according to Marx and Engels, naive enough to believe that once people, regardless of the class they belong to, understand the ethical implications of the current state of affairs, they will act so as to establish socialism. Unaware of the necessity of a 'violent' revolution based on class conflict, they dreamed of a 'peaceful' transformation of society. Here is how Marx and Engels express it:

They want to improve the condition of every member of society, even that of the most favoured. Hence, they habitually appeal to society at large, without the distinction of class; nay, by preference, to the ruling class. For how can people, when once they understand their system, fail to see in it the best possible plan of the best possible state of society?

Hence, they reject all political, and especially all revolutionary action; they wish to attain their ends by peaceful means, necessarily doomed to failure, and by the force of example, to pave the way for the new social Gospel. (Marx and Engels 2008, 79)

Finally, Marx and Engels criticize the disciples of utopian socialists for their experiments with small-scale communities. As it is evident from the quotation below, Marx and Engels see these attempts not only as wasteful but also troublesome, for they prevent revolutionary political activity.

Therefore, although the originators of these systems were, in many respects, revolutionary, their disciples have, in every case, formed mere reactionary sects. They hold fast by the original views of their masters, in opposition to the progressive historical development of the proletariat. They, therefore, 
endeavour, and that consistently, to deaden the class struggle and to reconcile the class antagonisms. They still dream of experimental realisation of their social utopias, of founding isolated 'phalanstères', of establishing 'Home Colonies', or setting up a 'Little Icaria' 8 - duodecimo editions of the New Jerusalem - and to realise all these castles in the air, they are compelled to appeal to the feelings and purses of the bourgeois. By degrees, they sink into the category of the reactionary [or] conservative socialists depicted above, differing from these only by more systematic pedantry, and by their fanatical and superstitious belief in the miraculous effects of their social science. (Marx and Engels 2008, 80-8I)

Given these three criticisms of Marx and Engels, how shall we understand the core of the disagreement? As we have noted above, the opposition between utopian and scientific socialism might be misleading unless we recognize that by the pejorative use of the term 'utopian' Marx and Engels target the ethical and idealist approach of utopian socialists and by the positive use of 'scientific' they want to promote their materialism. In The German Ideology, Marx and Engels contrast their materialism with idealism in the following manner:

In direct contrast to German philosophy which descends from heaven to earth, here it is a matter of ascending from earth to heaven. That is to say, not of setting out from what men say, imagine, conceive, nor from men as narrated, thought of, imagined, conceived, in order to arrive at men in the flesh; but setting out from real, active men, and on the basis of their real life-process demonstrating the development of the ideological reflexes and echoes of this life-process. The phantoms formed in the brains of men are also, necessarily, sublimates of their material life-process, which is empirically verifiable and bound to material premises. Morality, religion, metaphysics, and all the rest of ideology as well as the forms of consciousness corresponding to these, thus no longer retain the semblance of independence. They have no history, no development; but men, developing their material production and their material intercourse, alter, along with this their actual world, also their thinking and the products of their thinking. It is not consciousness that determines life, but life that determines consciousness. (Marx and Engels I998, 42)

Understood within the context of the controversy between material- 
ism and idealism, any appeal to utopia as the product of consciousness becomes an idealist view. That is why Marx and Engels claim in The Civil War in France: "The working class ... have no ready-made utopias to introduce... They have no ideals to realize, but to set free the elements of the new society with which old collapsing bourgeois society itself is pregnant." (Marx and Engels 2009, 42). Introducing utopia as the best possible society is the same as introducing an ethical approach to revolutionary practice. As Vincent Geoghegan rightly claims "Utopia can be seen as the good alternative, the outline of a better future, an 'ought' to the current 'is'." (Geoghegan 2008, I6). Proposing a utopia as an outline of a better future is to make an ethical claim. It is to argue that the current state is not what it ought to be. Utopia gives an outline of what ought to be, that is to say, what is ethical. Marx and Engels, however, avoid any appeal to such an ethical stance in their revolutionary practice. In The German Ideology, while criticizing Stirner, Marx and Engels say:

Communism is quite incomprehensible to our saint because the communists do not oppose egoism to selflessness or selflessness to egoism, nor do they express this contradiction theoretically either in its sentimental or in its high-flown ideological form; they rather demonstrate its material source, with which it disappears of itself. The communists do not preach morality at all, as Stirner does so extensively. They do not put to people the moral demand: love one another, do not be egoists, etc.; on the contrary, they are very well aware that egoism, just as much as selflessness, is in definite circumstances a necessary form of the self-assertion of individuals. (Marx and Engels 1998, 264)

The communists do not preach morality mainly because morality for Marx and Engels expresses the interests of the dominant class. They consider morality to be relative. Engels explains further in Anti-Dübring:

We therefore reject every attempt to impose on us any moral dogma whatsoever as an eternal, ultimate and forever immutable ethical law on the pretext that the moral world, too, has its permanent principles which stand above history and the differences between nations. We maintain on the contrary that all moral theories have been hitherto the product, in the last analysis, of the economic conditions of society obtaining at the time. And as society has hitherto moved in class an- 
tagonisms, morality has always been class morality; it has either justified the domination and the interests of the ruling class, or, ever since the oppressed class became powerful enough, it has represented its indignation against this domination and the future interests of the oppressed. That in this process there has on the whole been progress in morality, as in all other branches of human knowledge, no one will doubt. (Tucker (Editor) 1978, 726)

Furthermore, revolutionary practice does not require any ethical initiative if materialism is taken to be the motor of historical progress. In Socialism: Utopian and Scientific Engels explains:

Hegel had freed history from metaphysics - he had made it dialectic; but his conception of history was essentially idealistic. But now idealism was driven from its last refuge, the philosophy of history; now a materialistic treatment of history was propounded, and a method found of explaining man's "knowing" by his "being," instead of, as heretofore, his "being" by his "knowing."

From that time forward socialism was no longer an accidental discovery of this or that ingenious brain, but the necessary outcome of the struggle between two historically developed classes-the proletariat and the bourgeoisie. Its task was no longer to manufacture a system of society as perfect as possible, but to examine the historical-economic succession of events from which these classes and their antagonism had of necessity sprung, and to discover in the economic conditions thus created the means of ending the conflict. But the socialism of earlier days was as incompatible with this materialistic conception as the conception of Nature of the French materialists was with dialectics and modern natural science. (Tucker (Editor) $1978,699-700$ )

As Engels explicitly claims above, the problem with the utopian socialists is their idealist conception of a social movement, for "the socialism of earlier days was incompatible with this materialistic conception." According to Marx and Engels, the materialist mentioned above conception of a social movement is what makes their critique scientific. But what did Marx and Engels mean by 'scientific'? Did they think of the scientific analysis of social movements to be akin to natural sciences? In Economic and Philosophic Manuscripts of I844, Marx claims: 
History itself is a real part of natural history - of nature's coming to be a man. Natural science will in time subsume under itself the science of man, just as the science of man will subsume under itself natural science: there will be one science...

The social reality of nature, and human natural science, or the natural science about man, are identical terms. (Marx I988, III)

Marx and Engels, then, take social sciences to be on a par with natural sciences. Three basic elements of natural sciences are description, explanation and prediction. ${ }^{6}$ The possibility of prediction presupposes a certain sense of determinism supported by necessity in natural events and relations. Do social events and relations presuppose such a determinism? Do they come about out of necessity? If the material, more precisely, economic conditions determine the social events and relationships out of necessity, then such a view deserves to be called 'scientific,' but at the expense of human freedom of action. But without presupposing human freedom of action, ethics becomes a phantom. In other words, if human action is considered to be determined by material conditions, not by consciousness, there is no room for free will and without free will ethical responsibility turns out to be an empty notion.

What does the scientific method of Marx and Engels entail? (I) Determinism by material conditions or (2) Necessary material conditions for the possibility of communism? If (I) then there is no place for human ideas and will for being the author of history. If (2) there is room for human intervention. But this means that communism might only be one alternative among plausible future alternatives. In this case, there is a need for a utopian vision to mobilize people's ideas and will towards an ethical revolution. To the extent that revolution is thought to be determined by material conditions, to that extent ethical values are seen to be irrelevant to revolutionary practice. The question is not only the relevance of ethics but its possibility. The conception that action based on choice springs from ethical evaluation becomes an idealist. This brings us to the discussion between Eduard Bernstein and Rosa Luxemburg.

${ }^{6}$ See Murzban Jal's "The Irresistable Science of Karl Marx" for a Marxist vision of science as what has "the essential moments of description, explanation and prediction based on verifiable material princibles" 23. 


\section{Ethics (Idealism) vs. Science (Materialism): Bernstein and Luxemburg}

In The Preconditions of Socialism, Eduard Bernstein agrees with Marx and Engels that class conflict and economic factors play a role in social movements, but, unlike Marx and Engels, he explicitly opens space for ethical intervention:

However, because men pay ever greater attention to economic factors, it can easily seem as if these factors play a greater role today than they did before. This, however, is not the case... the level of economic development reached today leave ideological and ethical factors greater scope for independent activity than was formerly the case... In this way, the 'iron necessity of history' is curtailed... (Bernstein 1993, 19-20)

In response, Rosa Luxemburg in her article "Reform or Revolution" accuses Bernstein of being an idealist:

What, in that case, is the basis of Bernstein's program for the reform of society? Does it find support in definite tendencies of capitalist production? No. In the first place, he denies such tendencies. In the second place, the socialist transformation of production is for him the effect and not the cause of distribution. He cannot give his program a materialist base, because he has already overthrown the aims and the means of movement for socialism, and therefore its economic conditions. As a result he is obliged to construct himself an idealist base. (Luxemburg 2008, 84)

This idealist base is Bernstein's concern for the relevance of an ethical approach to revolutionary practice. Luxemburg argues that such an ethical outlook is idealist, for it does not recognize the economic necessity, the materialist basis of revolution:

"Why represent socialism as the consequence of economic compulsion?" he complains. "Why degrade man's understanding, his feeling for justice, his will?" (Vorwarts, March 26, I899). Bernstein's superlatively just distribution is to be attained thanks to man's free will, man's will acting not because of economic necessity, since his will itself is only an instrument, but because of man's comprehension of justice, because of man's idea of justice. (Luxemburg 2008, 84)

Both Bernstein and Luxemburg take themselves to be Marxists. Luxemburg, however, claims that it is fashionable to attack Marx's teach- 
ings by presenting such an attack as a further development of Marxian doctrine. In this sense, from Luxemburg's perspective, Bernstein is not actually a Marxist. As she puts it:

Today he who wants to pass as a socialist, and at the same time declare war on Marxian doctrine, the most stupendous product of the human mind in the century, must begin with involuntary esteem for Marx. He must begin by acknowledging himself to be his disciple, by seeking in Marx's own teachings the points of support for an attack on the latter, while he represents this attack as a further development of Marxian doctrine. On this account, we must, unconcerned by its outer forms, pick out the sheathed kernel of Bernstein's theory. (Luxemburg 2008, 42)

Indeed, if Luxemburg's theory of revolution represents a genuine Marxist perspective, Bernstein's view, which is in direct opposition to hers, cannot be called a Marxist thesis. Luxemburg's 'scientific' Marxism does not give any role to ethical concerns in bringing about revolution. On the contrary, attributing such a role, for Luxemburg, would mean sliding back to idealism. Marx's materialism is as scientific as any natural science can be. As Louis Althusser argues in "The Humanist Controversy":

The basic categories of Marxist philosophy (dialectical materialism) are materialism and dialectic. Materialism is based not on the ideological notions of Subject and Object, but on the distinction between matter and thought, the real and knowledge of the real - or, to put it differently and more precisely, the distinction between the real process and the process of knowledge; on the primacy of the real process over the process of knowledge... The dialectic determines the laws which govern these processes (real process and process of knowledge) in their dependence (primacy of the real process) and their relative autonomy, and so forth. (Althusser 2003, 26566)

Althusser's contrast is between scientific and ideological rather than utopian. Rightly so. For the scientific basis of Marxism is supposed to be its (dialectical) materialism and materialism is the thesis opposed to idealism. In "The Humanist Controversy," Althusser argues that Marx, in his mature period, dropped the theoretical humanism of his early stage and embraced a scientific approach. This is one of the most faithful interpre- 
tations of Marx. It is well known that Marx of Economic and Philosophic Manuscripts of I 844 was a humanist. Humanism is a philosophical anthropological thesis about human essence and an ethical outlook that promotes human flourishing in view of this essence. That is why some scholars aimed at reconciling Marx's humanism with an Aristotelian ethics. But some of these studies do not adequately discuss how to reconcile their thesis with the (dialectical) materialism of the mature Marx and his aversion of morality. ${ }^{7}$ In this sense, Althusser gives us a more faithful presentation of Marx's perspective. In agreement with our interpretation of Luxemburg's Marxism, ideological claims, for Althusser's Marx, also involve moral judgements. These humanist ideological notions might be relevant for morality, but, for that matter, they close off the field for understanding real problems and making scientific discoveries. This, Althusser explains in the following manner:

To put it schematically, the ideological notions in question here are merely transcriptions, with theoretical pretensions of existing state of affairs. In the final analysis, they depend on the balance of power in the class struggle: they are ideological prises de parti in favour of certain moral, religious and political 'values', and, by way of those values, certain political institutions, certain moral and religious prejudices, and the prejudice of morality and religion.

Therefore, far from opening up the theoretical field in which it would be possible to pose real problems scientifically, these ideological notions, which are basically nothing but theoretical transcriptions of actually existing solutions, have the function of preventively closing off the field they pretend to open up, thus making it impossible o pose any real problems or, consequently, make any pertinent discovery. (Althusser 2003, 274)

We have so far contemplated the relations between utopian, scientific, ethical, humanist, idealist, and materialist ways of understanding socialism, based on the mainstream Marxist debates. To summarize, we have seen that on the one hand we have a parallelism between ethical, idealist, humanist and utopian socialisms, and on the other hand we have another parallelism between materialist and scientific socialism. We have

\footnotetext{
7 The reason for this is that some of these approaches fail to distinguish between what Marx claims and what more can be said compatible with Marx's view. The former constitutes Marx's view while the latter is a Marxist thesis.
} 
explained what Marx and Engels took to be 'scientific', and why, for Marx and Engels, 'utopian' visions were not 'scientific'. On the one hand, we realized that a 'scientific' approach was used as opposed to the idealist one and in favour of the materialist approach. On the other hand, we saw that ethical intervention was considered to be an idealist approach by Marx and Engels. Furthermore, we pointed out a possible connection between humanism and ethics. Finally, we discovered that a utopian vision of socialism requires ethical guidance for acting in favour of revolution by providing a view of a better social world. In this way, we arrived at the connection between scientific and materialist theses on one side and at the opposite pole, we have the connection between utopian, ethical, idealist and humanist arguments.

In agreement with Althusser, we can claim that early Marx was a humanist with ethical sensibilities while late Marx was a materialist and scientific socialist. Is there a way of reconciling the early Marx's position with that of the late Marx's without contradiction? Early on we suggested that the scientific method of Marx and Engels, namely (dialectical) materialism, entails either (I) determinism by material conditions or (2) necessary material conditions for the possibility of utopian revolution. By this, there are two ways in which one can understand the relation between materialism and determinism. The first approach might be called full determinism, according to which material conditions fully determine social events and relations. The latter approach might be called partial determinism, according to which material conditions are necessary for the possibility of utopian revolution, but not sufficient; for social events and relations are determined by a combination of material conditions and human free action. The latter thesis is a blend of materialism and idealism, more precisely, it tries to avoid the 'either-or' approach: either ideas determine material conditions, or material conditions determine ideas. This approach just claims that there is a two-way relationship.

Now, we claimed that Althusser's interpretation of Marx's progress in two stages (the humanist stage followed by the scientific stage) is indeed supported by historical texts of Marx and Engels. But what we are interested here is not actually the textual meaning of these texts, for we do not primarily aim at finding out whether Marx himself endorsed full or 
partial determinism. We shall try to understand the truth of the matter. It seems to us that we need to go beyond the demarcation between materialism and idealism. We need to develop a new Marxist approach that reconciles materialism with idealism. This, however, implies that we shall re-organize Marx's ideas concerning scientific socialism, and present a new approach that entails partial determinism. Although we suggest that such a Marxist perspective is more plausible way to proceed, we do not further claim that this is what mature Marx aimed at. Most probably, he did not. But it is not the subject of this paper to argue for this historical thesis. Althusser has already accomplished this task for us. We are rather interested in finding out what more can be said for improving Marx's intuitions (that were expressed at his early stage) and his further analysis of the economy. This is then our first presupposition for the possibility of Marxist ethics, that is, material-economic conditions are necessary for the possibility of utopian revolution, but not sufficient. This claim should be the primary presupposition for any attempt to develop a Marxist theory of ethics, for it allows room for ethical intervention.

According to our Marxist thesis of partial determinism, material conditions are necessary but not sufficient, for we need the impact of ideas for the possibility of a conscious revolution, namely, a revolution that is based on the free endeavor of human beings. This is a blend of materialist and idealist thesis. The idealist side of this thesis implies that for the possibility of a conscious revolution, an ideal intervention, i.e., an intervention made on the basis of an ideal, a re-organization of human ideas, a perspective is required. When such an ideal intervention takes place according to a vision of utopia, a vision of a better society, an ethical vision of society, then it is called an ethical intervention.

In conclusion, for the possibility of Marxist ethics, one should allow room for ethical intervention in bringing about revolution. If ethical intervention is impossible, (that is, if full determinism by material conditions is taken to be true and ethical ideas are supposed to have no impact on revolution), then there is no meaning in developing a Marxist ethics. Marxist ethics then presupposes not only partial determinism but also the necessity of ethical intervention for the possibility of a utopian revo- 
lution, i.e., a revolution that is carried out according to a vision of utopia. ${ }^{8}$ This is then our second presupposition for the possibility of Marxist ethics: an ethical claim as a vision of utopia should guide the revolutionary practice. In other words, Marxist ethics should presuppose the possibility of utopian revolution.

The conclusive claim of this section is then the following: any attempt to develop Marxist ethics should address, "How is utopian/ethical revolution possible?" Now, the possibility of utopian/ethical revolution presupposes the existence of agents who are able to carry out that revolution. Hence, the question concerning how utopian revolution is possible presupposes that we have an answer to the question: "Who is able to carry out a utopian revolution?" This is, however, a Nietzschean question concerning the relevance of ethics to revolutionary practice. To answer this question, we shall now turn to Nietzsche.

\section{Nietzsche and the Question of Revolution: Concluding Remarks}

Who is able to tell the truth? This is Foucault's Nietzschean question, in the lecture notes that are published as Discourse and Truth. In our case, the crucial question concerning the possibility of revolution is: Who is able to carry out a utopian revolution? This is a Nietzschean Marxist question. But, at first sight, it might seem that a Marxist and a Nietzschean would give different answers. Is there a way of reconciling their answers? How can we support our above-mentioned Marxist thesis (which endorses partial determinism) with a Nietzschean thesis that will give us an answer to our question concerning the possibility of utopian revolution? ${ }^{9}$

8 In this context, 'utopian' and 'ethical' are interchangeable concepts. This is because, as we have explained before, an ethical vision of a better society in the future is called a utopian vision.

9 Here again, we need to distinguish between the view of Nietzsche and a Nietzschean view. The latter is a thesis that tries to improve Nietzsche's ideas. In this sense, it is a new perspective, for it attempts to re-organize the outlook of Nietzsche's various ideas. This new view is inevitably not Nietzsche's own view and it does not claim to present Nietzsche's own view. It is not interested in finding out what exactly Nietzsche 'intended' to say. For one, it does not doubt that Nietzsche's intention was to present the truth as he saw it. Hence, given our perspective of truth, how can we re-organize Nietzsche's ideas so as to present truth better? This is our question. And our intention in this section is to present a perspective that re-organizes Nietzsche's ideas in a new manner. Thus, we hope to achieve a better understanding of truth rather than a better understanding of the 
Before suggesting such a thesis, we shall determine one more related presupposition of our Marxist thesis (of partial determinism). As is well known, Marx analyzed the economic distribution of power. According to a mainstream Marxist (who endorses full determinism), however, the way in which economic power is distributed determines the way political power is distributed. But this is not wholly true. For it is initially political power that determines the economic distribution of power, which in turn redistributes the political power accordingly. Hence, without understanding the dynamics of how political power can be distributed, we cannot know how to change the way of distributing economic power, which is necessary for revolution. Our Marxist thesis of partial determinism should then endorse the primacy of political power. But what is political power? It is the power that enables one to influence others' understanding and choice about how political power needs to be distributed. Hence, our initial question is: How is political power supposed to be distributed initially? What would our Nietzschean say about this?

Nietzsche primarily explained the moral roots of developing a human culture. In On the Genealogy of Morality, he described two different types of character based on the mentality of Slave and Master morality. According to our Nietzschean, the character of Slave mentality (someone who thinks and feels according to the norms of Slave morality), is a nosayer to life. He is closed towards others. He has not established what is supposed to be good. He considers the other that seems to be his enemy as evil and believes that he is good just because he is opposed to the other who is supposed to be evil. First he determines an enemy with respect to which he positions himself as good. But there are no intrinsic qualities that the character of Slave mentality has that can be called good. According to this character, such intrinsic good qualities are irrelevant for determining who is supposed to be good. Good is automatically assigned to one's self. The character of Master mentality, however, first determines the values that are relevant for pursuing a good life. He then turns to himself and checks whether his character possesses required qualities compatible with these values, namely, virtues. Since it does, he calls him-

textual meaning of Nietzsche's view. This is what we have early on called abistorical approach to history of philosophy. 
self good and calls those who lack these virtues merely as bad, i.e., base. He does not have a conception of evil, for he can even respect his enemies who are virtuous as well.

Our Nietzschean further claims that the distinction between Master and Slave morality is primarily based on a difference in their methodology of establishing an ethical perspective. Do you first choose an enemy and call him/her evil, and hence, begin with an arbitrary determination of evil and consider yourself good just because you are opposed to whom you distinguished as an evil enemy? Or do you first re-evaluate values and choose to give value to some of them more than others? For, you either possess these values or saw others who possess them, and hence observed that they were good for life. And that is why you value these values more and consider those who lack them a base or bad? Is this the way you develop an ethical perspective? This is the healthy way of approaching ethics. Slave morality, however, is an unhealthy (even sick) way. Since the methodology of Slave morality is malfunctioning, it cannot achieve a perspective that is truly ethical. The perspective it presents as ethical is distorted. Master morality, on the other hand, can achieve an ethical perspective for it is a healthy approach to ethics, and its methodology is functioning well.

But what is an ethical perspective? An ethical perspective, by definition, is a perspective that has an ethical claim, a claim about what is supposed to be valuable/good for life. Hence each ethical perspective aims at something good, and we call this a good utopia when the question is about how to distribute political power. Notice, however, that according to our Nietzschean, there may be multiple ethical perspectives, for there is no 'absolute' right or wrong for an ethical perspective. All there is 'a matter of degree.' The value of an ethical perspective can only be seen/understood when it is compared with another one. It might be better or worse. Hence, a utopian vision of future, a new ethical perspective about the distribution of political power can only be developed in comparison to the dominant perspective of the present. It aims at not an unknown best society but a better one, better than what is known to be dominant at present.

A vision of utopia, we said, is an ethical perspective about the distri- 
bution of political power. How is this related to Nietzsche's will to power? According to our Nietzschean, 'will to power' when it belongs distinctively to human beings, shows itself as the will to political power. Since political power is the power of influencing others and all people have the will to be able to influence others, all people have the will to political power (although their strength might be different). Question concerning the distribution of political power is primarily a question about who is going to be the representative of a group of people. This representative can either be a ruler or a leader. Nietzsche considered any relationship between the ruler and the ruled problematic. He rather sought for a person who could be a leader, that is, who could re-evaluate the values and be a law-giver. According to our Nietzschean, he was talking about the establishment of a new way of distributing political power, which goes beyond the ruler-ruled relationship. A person with an ethical power, namely a virtuous person, who could re-evaluate the values of the established system and suggest a new way of rank ordering among the values, a new ethical perspective, would be the legitimate candidate for the status of leadership. But such a person is either rare among humans or even absent, and hence we might claim that such persons can be named Nietzsche's 'super-human,' a new form of homo sapiens, an actualized human with ethical power.

Who has the political power in a culture based on Slave morality? The priest as the shepherd of the masses who have the Slave mentality. We know enough about what kind of role the priest plays with regard to reproducing the relationship between the ruler and the ruled. The crucial point is that due to the distorted perspective of what is ethical, the political distribution of power is executed according to the way in which the ruled are ruled by a ruler. How would the political power in a culture of super-humans distribute? A culture that would have its methodological roots in Master morality, but could overcome the ancient applications of it, namely, ancient ethical perspectives, for it would propose a new ethical perspective according to the needs of the present. Our Nietzschean claims that whoever has the ethical power most becomes the leader, that is, an exemplary to a group of people, who trust the leader due to his character qualities and seek being like him. Hence, this is the main claim 
of our ethical perspective concerning the way in which our Nietzschean would explain how political power should be distributed.

A mainstream Marxist, however, believes that it is the economic conditions that determine the distribution of political power. He would be right for the established systems. But who establishes such a system? Either nature or humans. Are humans conditioned by nature to a particular way of distributing political power? What about bees? Are they conditioned by nature to a certain kind of social organization? Yes. But humans are not. Over their history, humans have experimented with distributing political power in various ways. That is why they should be called 'political' animals, not because of the fact that they live in cities, but because of their capacity for developing different ways in which they are related to each other. They are capable of creating new ways of distributing political power that determines how they are related to each other. Human societies are based on artificial ways of distributing political power, for they are not necessitated by nature. Humans can create and choose their political organization.

Who is able to create a better way of distributing political power? The ancient philosophers of Greece, and Nietzsche were right. It is the healthy people, both in body and soul, the blessed, the noble. ${ }^{\mathrm{IO}}$ Economic conditions, however, are necessary but not sufficient conditions for the possibility of revolution for establishing such a political organization. It is people's understanding and will to be good, that is required. ${ }^{\text {II }}$ We human beings are free animals, or we can become human to the extent that we are free. If we are to be determined by economic necessity, then we will be reduced to the position of (a merely more complicated) animal.

Returning to our crucial question of this section, that is, 'Who is able to carry out a utopian revolution?', a mainstream Marxist and our

Io This is what Nietzsche learned from the ancient philosophers of Greece. But Nietzsche believed in the diversity of rank ordering among values and vitues. He was realist about values and virtues themselves but anti-realist about the way in which they can be related to each other or organized. Each culture has a different rank ordering of values, a different ethical perspective. Each shows us truth seen from a certain perspective. The more ethical perspectives we have, the better we approach to truth, says Nietzsche.

II Recall, however, that this partial determinism is what our Marxist thesis endorses. A mainstream Marxist, however, suggests that there is full determinism by material conditions, which leaves no room for ethical intervention. 
Nietzschean give different answers. According to our Nietzschean, it is the people with ethical power who are able/supposed to carry out a utopian revolution. A mainstream Marxist, however, believes that it is the proletariat, the most disadvantaged economic group. But what could be the motivation behind such a group of people to carry out a revolution? What kind of will to power do they have? Primarily, they have a personal interest in putting an end to their poverty. Also, they might (or might not) also have a vision of a better society based on a fair distribution of economic power. But does the proletariat represent by definition people who can develop and understand such a utopia and have an ethical power to bring it? No, not necessarily. They might or they might not. If not, that is, if they act merely by their own interest, they will take over the political power and reproduce the same manner of distributing political and economic power based on the ruler-ruled relationship, which is called enslavement.

Now, any social organization which allows accumulating economic power, that is capital, through the labour of another person is a form of enslavement. Capitalism is the latest version of an economic system based on enslavement. It does not follow from being enslaved that the proletariat will necessarily have the virtues required for ending enslavement as such. According to our Nietzschean, only people who have ethical power are capable of carrying out a utopian revolution that abolishes enslavement. ${ }^{\mathrm{I} 2}$ Our last question should then be about the means of revolution. For ends cannot justify the means. On the contrary, the means is an indication of what your end aims to achieve. In order for the revolution to be successful, one needs to gain political power. But how is political power gained? Political power is the power of influencing others. All humans have a will to political power. They want to influence each other. But how do they attempt to influence each other? What are the means of gaining political power?

\footnotetext{
${ }^{12}$ Interestingly, societies, that were based on and approved of enslavery, were guided by the distorted perspective provided by Slave morality and socieites without enslavement were guided by an ethical perspective endorsed by Master morality. Does Master morality approve of enslaving people? Or is it by definition against enslavement? Evidently a real master, namely, a leader or a teacher, would not enslave his/her followers or pupils. This is what our Nietzschean claims.
} 
Now, some use force and some use persuasion. These are the two essential means of achieving political power. Political power based on force is a corrupt way of influencing others and establishing political authority. The only persuasion through rhetoric is a legitimate way of gaining political power. But this also has two types: One is based on truth, the other on deception, for there are two kinds of applied rhetoric, truthful and deceptive. Deceptive forms of gaining political power based on persuasion, aim at the same ruler-ruled relationship (namely, enslavement) that political power based on force achieves directly. Only correct ways of gaining political power based on persuasion are the good ways of carrying out a revolution, the kind of revolution which abolishes enslavement and distributes political power according to the relationship between the leaders and the followers, or the teachers and the students. This is what indeed we call a utopian revolution. A utopian revolution is a conscious attempt of human beings to change the political realm, which endorses enslavement, according to a vision of utopia that abolishes enslavement.

Hence, an ethical perspective on how to distribute political power, namely, a vision of utopia, is necessary for the possibility of a revolution that abolishes enslavement and establishes a society suitable for humans. Nietzsche was right, we need to re-evaluate values and rank order them so as to establish a new ethical perspective, and this can be done only by those of us who have ethical power. Can such an ethical thesis be Marxist? According to us, it would be a thesis with Marxist sensibilities and based on Marx's analysis of the economic distribution of power. Is this sufficient to call it Marxist? It does not matter much. But it would be misleading to call it Marxist unless we recognize the ethical contribution of Nietzsche. Hence it should rather be called a Nietzschean Marxist thesis of ethics. Elaborating such an argument is, however, beyond the limits of this paper, which has just proposed a Nietzschean Marxist claim about the relevance of ethics for the possibility of utopian revolution and laid out the presuppositions of developing a Nietzschean Marxist theory of ethics. We found out (with the help of Nietzsche and Marx) that material conditions and an ethical perspective are both necessary for the possibility of utopian revolution that abolishes enslavement. The conclusion of this paper entails that we urgently need an ethical perspective, a 
new way of perceiving ethics (based on a reconciliation of Nietzsche and Marx). This further entails that there should be cooperation between the Nietzscheans and the Marxists of today, who have ethical power, in order to develop a Nietzschean Marxist theory and application of ethics.

\section{References}

Althusser, L. (2003). The Humanist Controversy and Other Writings. (Trans. C. M. Goshgarian). London: Verso Publications.

Bernstein, E. (1993). The Preconditions of Socialism. (Ed. \& trans. H. Tudor). Cambridge: Cambridge University Press.

Blackledge P. (2012). Marxism and Ethics: Freedom, Desire and Revolution. Albany: State University of New York Press.

Durkheim, E. (2009). Socialism and Saint Simon. (Trans. C. Sattler). London: Routledge \& Taylor and Francis.

Engels, F. (1908). Socialism: Utopian and Scientific. (Trans. E. Aveling). Chicago: Charles H. Kerr Company.

Fourier, C. (1971). The Utopian Vision of Charles Fourier: Selected Texts on Work, Love and Passionate Attraction. (Eds. \& trans. J. Beecher \& R. Bienvenu). Boston: Beacon Press.

Geoghegan, V. (2008). Utopianism and Marxism. Bern: Verlag Peter Lang.

Jal, M. (20I0). The Irresistible Science of Karl Marx. Social Scientist, 38 (5-6), 22-34.

Kumar, K. (1990). Utopian Thought and Communal Practice. Theory and Society, I9, I-35.

Leopold, D. (2007). Socialism and (the Rejection of) Utopia. Fournal of Political Ideologies, 12 (3), 219-237.

Levitas, R. (2004). Beyond Bourgeois Right: Freedom, Equality and Utopia in Marx and Morris. The European Legacy, 9 (5), 605-618.

Lovell, D. W. (2004). Marx's Utopian Legacy. The European Legacy, 9 (5), 629-640.

Luxemburg, R. (2008). The Essential Rosa Luxemburg: Reform or Revolution and The Mass Strike. Ed. H. Scott). Chicago: Haymarker Books.

Marx, K. \& Engels, F. (1980). On the Paris Commune. Moscow: Progress Publishers.

Marx, K. \& Engels, F. (1998). The German Ideology. New York: Prometheus Books.

Marx, K. \& Engels, F. (2008). The Manifesto of the Communist Party. (Trans. S. 
Moore) London: Pluto Press.

Marx, K. \& Engels, F. 2009. The Civil War in France. London: Dodo Press.

Marx, K. (1988). Economic and Philosophical Manuscripts of I844. (Trans. M. Milligan). New York: Prometheus Books.

Nietzsche, F. (20II). On the Genealogy of Morality. (Trans. C. Diethe). Cambridge: Cambridge University Press.

Owen, R. (199I). A New Way of Society and Other Writings. (Ed. G. Claeys). London: Penguin Books.

Paden, R. (2002). Marx's Critique of the Utopian Socialists. Utopian Studies, I3 (2), 67-91.

Thomas, P. (2008). Marxism and Scientific Socialism from Engels to Althusser. New York: Routledge \& Taylor and Francis.

Tucker, R. C. (Ed.) (1978). The Marx-Engels Reader. New York: W. W. Norton \& Company.

Yassour, A. (1983). Communism and Utopia: Marx, Engels and Fourier. Studies in Soviet Thought, 26 (3), 217-227.

Öz: Marx bir etik kuramı geliștirmekten kaçınmıș ve ütopyacı sosyalistleri eleștirmiștir. Her ne kadar Marx'ın bu iki konuya olan yaklașımı felsefi kaynaklarda farklı konular olarak tartıșılmıșsa da, biz bu ikisinin Marx'ta aynı kaynağa dayandığını savunacağız. Marx'ın bu eleștirilerinin kaynağında onun bilimsel sosyalizme olan adanmıșlığı yatmaktadır. Öncelikli olarak Marx'ın anladığı șekliyle ütopyacı ve bilimsel sosyalizm arasındaki farkı tartışacağız. Bu tartışmada yer alan Marksist bakıș açılarını özetledikten sonra Marksizmi etikle uzlaștırmaya çalıșan her çabanın özünde ütopyacı olması gerektiğini ileri süreceğiz. Son olarak, Marksist bir etik kuramı geliștirmek için neden bir ütopya kurgulamaya ihtiyaç olduğunu Nietzscheci argümanlar vererek destekleyeceğiz.

Anahtar Kelimeler: Marx, Nietzsche, etik, ahlak, ütopya, devrim. 